\title{
薬剤性腎障害：最近の話題
}

\section{三井亜希子 鶴岡秀一}

これまで, 薬剤性腎障害（drug-induced kidney injury：DKI）の定義とその予防や治療に関して明確なものは なく, 発症頻度の詳細や病態の体系的理解に結び付く報告も少なかった. 2016年, 我が国で初めて「薬剤性腎障 害診療ガイドライン 2016」(日本医療研究開発機構 腎疾患実用化研究事業, 2016年) が刊行され, 具体的な概 念の提唱と障害機序をもとに分類・診断する試みがなされた. 薬剤性腎障害は, 急激に腎機能が悪化する急性腎 障害 (acute kidney injury：AKI）だけでなく, 慢性的に緩徐に腎機能が悪化する慢性腎臓病 (chronic kidney disease : CKD) やネフローゼを呈する場合もあり, 症状・経過は多彩である. 発症機序は, 予測可能なものと 予測不可能な特異体質によるものに大別され, 特に前者では投与前にリスクファクターの評価と対策を講じるこ とで発症を抑制できる可能性がある. また, DKIを疑った場合には, 原因薬剤を可能な限り早期に同定・中止す ることが基本となる. 今後は, データ集積, 得られたエビデンスの検証, 国際比較により薬剤性腎障害診療の確 立が進むと考えられる.

〔日内会誌 $107 ：$ 103～109，2018〕

\section{Key words 薬剤性腎障害，診療ガイドライン，急性腎障害，慢性腎臓病}

\section{はじめに}

薬剤に起因する腎機能障害は，薬剤性腎障害 （drug-induced kidney injury：DKI）として日常 臨床においてしばしば経験される。近年，急性 腎障害（acute kidney injury：AKI）という概念 が提唱され，入院中のAKI症例の約 15～25\%は 薬剤が原因であると報告されている ${ }^{1,2)}$. しか し, 薬剤性腎障害は, 薬剤投与後に急激に腎機 能が悪化するAKIのパターンだけでなく，慢性 的に緩徐に腎機能が悪化する慢性腎臓病 (chronic kidney disease : CKD) や高度蛋白尿に よりネフローゼを呈してくるパターンもあり, 症状・経過は多彩であることが特徴である.ま
た, 全ての薬剤は副作用を引き起こす可能性が あり, 併用薬剤が複数あった場合, 原因薬剤の 同定はしばしば困難となる。薬剤性腎障害とい う言葉はよく使われるが, これまで薬剤性腎障 害の定義やその予防・治療に関して明確なもの はなく, また, 発症頻度の詳細や病態の体系的理 解に結び付く報告も少ないのが現状であった。

そのようななか, 近年, drug-induced kidney disease(DIKD)やdrug-induced kidney injury(DKI) といった用語と共に具体的な概念が提唱され, 薬剤に起因する腎機能障害を障害機序や障害部 位をもとに分類し, 時間経過も加味して体系的 に分類・診断する試みがなされている ${ }^{3 \sim 5)}$. 我 が国でも，昨年，薬羭投与を受ける患者の医療 


\title{
表 1 薬剤性腎障害の定義と診断 ${ }^{4)}$
}

\author{
《定義》 \\ 薬剂の投与により，新たに発症した腎障害，あるいは既存の腎障害のさらなる悪化を認める場合 \\ 《診断》 \\ 1）該当する薬剤の投与後に新たに発生した腎障害であること. \\ 2）該当薬剤の中止により腎障害の消失，進行の停止を認めること. \\ 上記の 1)，2）があって他の原因が否定できる場合に診断できる. また，腎障害の判定は，CKD \\ あるいは AKI の指針に準じる。
}

に携わる全ての医療者（腎臓専門医だけでな く，一般内科医，かかりつけ医，投薬指導にあ たる薬剤師の方々）に向けて「薬剤性腎障害診 療ガイドライン2016」（日本医療研究開発機構 腎疾患実用化研究事業，2016年）が刊行され $た^{4,5)}$.

我が国において, CKD患者は成人の 8 人に 1 人 とされ，人口の高齢化により今後さらに増加す ることが予想されている. CKD患者は, 糖尿病 や高血圧等の生活習慣病に関連した基礎疾患を 複数罹患し，さまざまな薬剤による治療を受け ているが，それと共に，悪性腫瘍，感染症，炎 症性疾患の罹患率も高く, 一般人口に比べて薬 剂治療を受ける頻度が高い。また, 薬剤の主要 な排泄経路である腎臓に機能障害が生じている ことから，薬剤による腎機能障害が惹起されや すく, AKIの発症リスク, CKDの進展リスクが高 いことが指摘されている。このような観点か ら, 薬剤性腎障害を早期に診断し, 適切な予防・ 治療を行うことは, CKDから末期腎不全への進 展を抑制するために非常に重要である。

\section{1. 薬棛性腎障害の診断とその問題点}

これまでに薬剤性腎障害の明確な定義や診断 基準はなかったが,「薬剤性腎障害診療ガイドラ イン2016」では, 『薬剤の投与により, 新たに 発症した腎障害, あるいは既存の腎障害のさら なる悪化を認める場合』と定義され, 診断基準 に関しても明記されている4,5)(表 1)。診断に際
しての注意点として，1）薬剤投与から発症ま での時間が個々の薬剤で異なること，2）既存 の腎障害の存在等により診断に難渋すること, 3）原因と推定される薬剤も複数が該当し, 確 定診断は困難なことが多々あること，4）時に 腎障害が固定して改善しないこと，長期に亘り 緩徐に進行する場合があること, 以上の 4 点が 挙げられており, 薬剤性腎障害の診断ならびに 原因薬劑の特定がしばしば困難で予後不良な場 合があることが言及されている。また, Mehta らは，同時期にBradford Hill基準を盛り込んだ 診断基準を提唱し, 薬剤性腎障害の発症様式・ 経過には薬剂によって急性のものから亜急性, 慢性のものがあることを示している3)(図 1).

薬剤性腎障害の診断と後述の分類に関して は, 診断の確実性・有用性が高いことが重要と 考えられ, 今後, より使いやすく, 再現性の高 いものへと改訂されていくことが予想される. 薬剤による他の臓器障害を例に考えてみると, 薬物性肝障害は，1）発症までの期間，2）薬物 中止後の経過，3）危険因子，4）薬物以外の原 因の有無，5）その薬物による過去の肝障害の 報告，6）好酸球増多，7）DLST（drug-induced lymphocyte stimulation test)，8）偶然の再投与 が行われたときの反応, 以上 8 項目についてス コアリングを行ったうえで診断しており，その 有用性も示されてきている6)。薬剤性腎障害の 診断においても, 再現性が高く, 診断の確実性 の高い, スコアリングツールの導入が考慮され るべきであろう。薬剤による有害事象に関して 


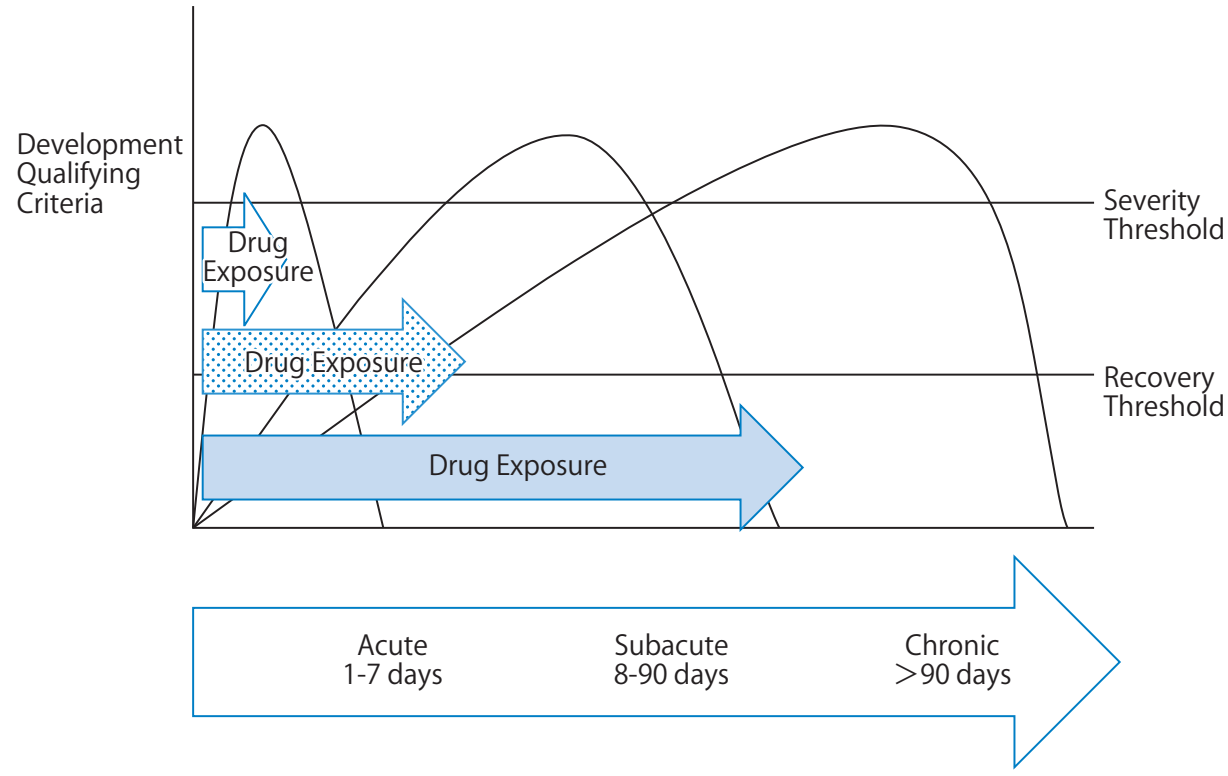

図 1 薬剤性腎障害の発症様式

均一化された記述・記載が行われれば, 情報の 共有が簡便になり, 併せて, 電子カルテが採用 されていれば，膨大なデータの抽出及び解析も 可能となる.

\section{2. 薬剤性腎障害の発症機序}

薬剂性腎障害の発症機序は, 発症の予測が可 能なもの（主に用量依存性・中毒性腎障害）と 予測が不可能な特異体質によるもの（主にアレ ルギー性・過敏性腎障害）と2つに大別される。 アミノグリコシド系抗菌薬のような濃度依存性 の腎機能障害（用量依存性・中毒性腎障害）を 起こす薬剤を投与する際は, 発症の予測が可能 で，診断も比較的容易なことが多い。また， therapeutic drug monitoring (TDM) による薬剤 投与設計や事前の予防策を講じることにより, 発症をある程度抑制できる。一方, 特異体質に よる腎障害（アレルギー性・過敏性腎障害）は， 発症の予測が不可能で, 原因薬剤の特定・確定 診断,また，当然のことながら発症の予防も困
難である.

「薬剤性腎障害診療ガイドライン2016」で は, 主に発症機序に基づいて, 臨床病型も加味 された分類となっている（表2 ${ }^{4)}$. 一方で, 古 くは1977年にDrug-related syndromes in clinical nephrologyと題して, 以下のように臨床病型に 基づいて，1）acute renal failure，2）chronic renal failure, 3) nephrotic syndrome, 4) fluid-electrolyte disorders, 5) acid-base disturbances, 6) uremic symptom-complex の6つに 分けることができると記載されている77). 2015 年のMehta らの報告では, 発症機序と臨床病型 の両方を採用し，表3のように分類している3 ${ }^{3)}$. さらに, 形態学的な所見に基づいて, 障害部位 により，1）糸球体障害，2）尿細管障害，3）腎 間質障害，4）腎血管障害，に分けて病態を把 握するアプローチもある ${ }^{8)}$. これらの分類は, 必ずしも全てを網羅しておらず，クリアカット に区別できるものではない.

また，同一薬浏が異なった機序，異なった部 位に作用し，腎障害を発症する可能性があるこ 
表 2 薬剤性腎障害の発症機序による分類 ${ }^{4}$

\begin{tabular}{|c|c|c|c|}
\hline 発症機序 & 主な臨床病型 & 病態 & 主な薬剤 \\
\hline \multirow{5}{*}{ 中毒性 } & \multirow[t]{2}{*}{ AKI, CKD } & ATN & $\begin{array}{l}\text { アミノグリコシド系抗菌薬，白金製 } \\
\text { 凨，ヨード造影剤，バンコマイジ， } \\
\text { コリスチン，浸透圧製剤 }\end{array}$ \\
\hline & & TMA & $\begin{array}{l}\text { カルシニューリン阻害薬，マイトマ } \\
\text { イシンC }\end{array}$ \\
\hline & CKD & $\mathrm{CIN}$ & NSAIDs，重金属，アリトロキア酸 \\
\hline & $\begin{array}{l}\text { 近位尿細管障害（Fanconi } \\
\text { 症候群，RTA） }\end{array}$ & & アミノグリコシド系抗菌薬 \\
\hline & $\begin{array}{l}\text { 遠位尿細管障害 (尿濃縮障 } \\
\text { 害, RTA，高カリウム血症) }\end{array}$ & & $\begin{array}{l}\text { リチウム製剤，アムホテリシン B, } \\
\text { ST合剤，カルシニーーリン阻害薬 }\end{array}$ \\
\hline \multirow{5}{*}{$\begin{array}{l}\text { アレルギー性・ } \\
\text { 免疫学的機序 }\end{array}$} & \multirow{3}{*}{ 然 } & AIN & $\begin{array}{l}\text { 抗菌薬， } \mathrm{H}_{2} \text { ブロッカー，NSAIDs 等 } \\
\text { 多数 }\end{array}$ \\
\hline & & 半月体形成性腎炎 & D-ペニシラミン，ブシラミン \\
\hline & & ANCA 関連血管炎 & $\begin{array}{l}\text { PTU， アロプリノール，D-ペニシラ } \\
\text { ミン }\end{array}$ \\
\hline & \multirow[t]{2}{*}{ 蛋白尿，ネフローゼ } & MCNS & $\begin{array}{l}\text { 金製剤, D-ペニシラ } \\
\text { リチウム製剤, インタープェ NSAIDs, } \\
\text { トリメタジオン }\end{array}$ \\
\hline & & MN & $\begin{array}{l}\text { 金製剂，D-ペニシラミン，ブシラミ } \\
\text { ， NSAIDs，インフリキシマブ }\end{array}$ \\
\hline \multirow{5}{*}{ 間接毒性 } & \multirow[t]{2}{*}{ AKI } & $\begin{array}{l}\text { 堅血流量低下（脱水・血圧低下に } \\
\text { 伴亏糸球体ろ過量の低下，尿細管 } \\
\text { 障害) }\end{array}$ & $\begin{array}{l}\text { NSAIDs，RAS 阻害薬（ACEI，ARB， } \\
\text { 抗アルドステロ薬） }\end{array}$ \\
\hline & & 横紋筋融解症による尿細管障害 & $\begin{array}{l}\text { 各種向精神薬, スタチン, フィブラー } \\
\text { 卜系楽 }\end{array}$ \\
\hline & 多尿，AKI & $\begin{array}{l}\text { 高カルシウムム血症による浸透圧利 } \\
\text { 㽷，脱水による氺細管障害 }\end{array}$ & ビタミン D 製剤，カルシウム製剤 \\
\hline & \multirow{2}{*}{ 電解質異常，CKD } & $\begin{array}{l}\text { 主に遠位尿細管障害による低ナト } \\
\text { リウム血症，低カリム血症 }\end{array}$ & NSAIDs \\
\hline & & $\begin{array}{l}\text { 慢性低カリウム血症による尿細管 } \\
\text { 障害 }\end{array}$ & 利尿薬，下剂 \\
\hline \multirow[b]{2}{*}{ 尿路閉塞 } & \multirow[b]{2}{*}{ AKI，尿路結石，水腎症 } & 腫瘍崩壊症候群による尿細管閉塞 & 抗癌薬 \\
\hline & & 結晶形成による尿細管閉塞 & $\begin{array}{l}\text { 抗ウイルス薬，抗菌薬の一部，トピ } \\
\text { ラマート }\end{array}$ \\
\hline
\end{tabular}

とにも留意しなければならない, 具体例とし て，非ステロイド性抗炎症薬（non-steroidal anti-inflammatory drugs : NSAIDs）が挙げられ る. NSAIDsは, 解熱鎮痛効果を目的として日常 臨床で使用される頻度の高い薬剤である。その 薬理作用から，脱水・血圧低下時には容易に腎 虚血を起こし，RAS (renin-angiotensin system) 阻害薬との併用によりさらに助長されることが 知られている。一方で, 表2にもあるように, 急性・慢性の尿細管間質障害やネフローゼ症候
群を発症するケースもあり，さまざまな腎障害 を起こす可能性がある。

\section{3. 薬剤性腎障害の疫学}

薬剤性腎障害の正確な発生率を把握すること は困難であるが，海外の報告では，薬剤による 有害事象の症状別頻度のデータから, 消化器症 状 (22.1\%) に次いで腎機能障害/電解質異常 (16.7\%）が多い結果となっている9). 
表 3 薬剤性腎障害の臨床病型による分類 3

\begin{tabular}{|c|c|c|c|c|}
\hline 㾁病型 & AKI & 糸球体障害 & 尿路閉塞 & 尿細管機能障害 \\
\hline 特徵 & $\begin{array}{l}\text { ATN } \\
\text { AIN } \\
\text { 浸透圧腎症 }\end{array}$ & $\begin{array}{l}\text { 血尿 } \\
\text { 蛋白尿 }\end{array}$ & $\begin{array}{l}\text { 結晶尿 } \\
\text { 尿路結石 } \\
\text { 水腎症 }\end{array}$ & $\begin{array}{l}\text { RTA } \\
\text { ファンコニ症候群 } \\
\text { SIADH } \\
\text { 尿崩症 }\end{array}$ \\
\hline
\end{tabular}

\begin{tabular}{|c|c|c|c|c|c|c|c|c|c|c|}
\hline \multirow{2}{*}{$\begin{array}{l}\text { 臨床病型 } \\
\text { 発症機序 }\end{array}$} & \multicolumn{2}{|c|}{ AKI } & \multicolumn{2}{|c|}{ 糸球体障害 } & \multicolumn{2}{|c|}{ 尿路閉塞 } & \multicolumn{2}{|c|}{$\begin{array}{c}\text { 尿細管機能 } \\
\text { 障害 } \\
\end{array}$} & \multirow{2}{*}{ 経過 } & \multirow{2}{*}{ 遺伝的機序 } \\
\hline & $\begin{array}{c}\text { type } \\
\text { A }\end{array}$ & $\begin{array}{c}\text { type } \\
\text { B }\end{array}$ & $\begin{array}{c}\text { type } \\
\text { A }\end{array}$ & $\begin{array}{c}\text { type } \\
\text { B }\end{array}$ & $\begin{array}{c}\text { type } \\
\text { A }\end{array}$ & $\begin{array}{c}\text { type } \\
\text { B }\end{array}$ & $\begin{array}{l}\text { type } \\
\text { A }\end{array}$ & $\begin{array}{l}\text { type } \\
\text { B }\end{array}$ & & \\
\hline アミノグリコシド & $\bigcirc$ & & & & & & & & 急性・亜急性 & メガリン，カテプシン \\
\hline アシクロビル & & & & & $\bigcirc$ & & & & 亜急性 & OAT \\
\hline シクロスポリン & $\bigcirc$ & $\bigcirc$ & & & & & & & 急性・亜急性 & CYP3A - P 糖蛋白 \\
\hline シスプラチン & & & & & & & $\bigcirc$ & & 亜急性・慢性 & OAT \\
\hline セファゾリン & & 0 & & & & & & & 亜急性 & HLA \\
\hline ヒドララジン & & & & $\bigcirc$ & & & & & 亜急性・慢性 & HLA \\
\hline ベバシツマブ & & & $\bigcirc$ & & & & $\bigcirc$ & & 急性・亜急性 & VEGF \\
\hline リチウム & & & $\bigcirc$ & & & & & & 亜急性・慢性 & VA 受容体 \\
\hline
\end{tabular}

type A；用量依存性・中毒性障害

type B ; アレルギ一性・過敏性障害（文献では“idiosyncratic”という用語が用いられている）

我が国において，2007～2009年に行われた 薬剤性腎障害に関するアンケート調査（厚生労 働科学研究腎疾患対策事業）の結果では, 腎臟 専門医が常駐する施設における全入院患者の 0.94\%が薬剤性腎障害による入院であった ${ }^{4)}$.原 因薬剤は, 多い順にNSAIDs, 抗腫瘍薬, 抗菌薬, 造影剤が挙げられている。臨床所見では, AKIの パターンが 3 分の 1 以上と最も多く, 次いで皮 疹，尿蛋白であった。予後に関しては，3分の 1 の症例が回復できず，高齢者（65歳以上）では 腎機能回復までの期間が長かったとされている。

また, 日本腎臓学会主導による日本腎生検レ ジストリー（Japan Renal Biopsy Registry : J-RBR）システムの登録症例（2007～2015年） の解析では, $1.24 \%(26,535$ 症例中 328 症例) が臨床病理学的（腎生検所見を含む）に薬剤性 腎障害と診断されている10)。年齢層別の発症頻 度は，若年者（10歳代，0.62\%）に比べて高齢 者（60～69歳，1.86\%）が約 3倍で，60歳代 まで連続して増加しており，これまでの既報と
同様に年齢の上昇がリスクファクターになるこ とが推測される (図2)。病理組織型では, 糸球 体疾患 105 例 (32.0\%)，急性間質性腎疾患 87 例 $(26.5 \%)$ ，慢性間質性腎疾患 72 例（22.0\%） が上位を占めていた。急性・慢性間質性疾患及 び糸球体疾患におけるCGA（cause，GFR，albuminuria）分類の高リスク群（未期腎不全）の頻 度は，それぞれ75.9\%，64.9\%，33.3\%と間質 性疾患で高率であり，間質障害が予後不良であ ると予測される。

\section{4. 薬剤性腎障害の予防と治療}

薬剤性腎障害は, 発症機序の観点から予測が 可能なものと予測が不可能な特異体質によるも のとに分けられる. 投与前にリスクファクター の評価を行い，対策を講じることで，特に用量 依存性・中毒性腎障害は発症を抑制できる可能 性がある.このことから, 薬剤投与時には以下 のような評価を行う4). 


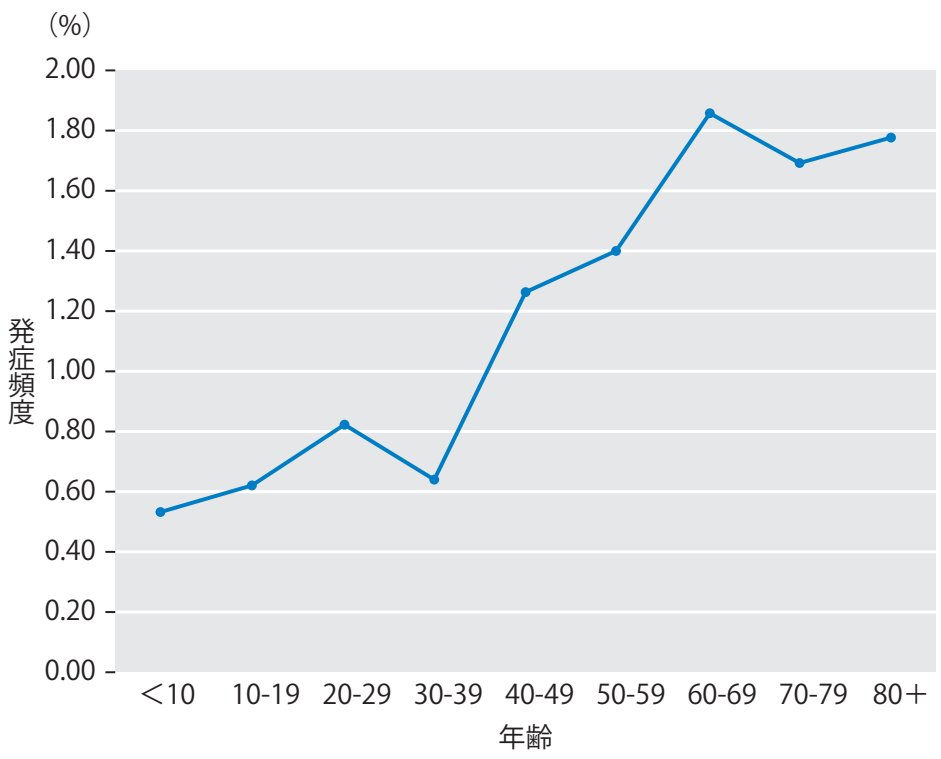

図 2 薬剂性腎障害年齢別発症頻度

\section{薬剤投与時のチェック項目}

1）基礎疾患の確認

2）薬剤の排泄経路（腎排泄型か, 肝代謝・胆 汁排泄型か）の確認

3）腎機能の確認

4）年齢

（特に高齢者では,潜在的な腎機能低下の可能性）

5）全身状態の評価（特に脱水はないか）

6）併用薬の確認

7）薬剤アレルギー歴の確認

これらの評価と共に, 腎血流量, 尿量を確保 するため, 必要に応じて, 細胞外液の補充を行 う。また, 治療としては, 薬㓮性腎障害を疑つ た場合には，原因と考えられる薬剤を可能な限 り早期に同定・中止するのが基本である，薬剤 性急性間質性腎炎に関しては, 被疑薬を中止し ても腎機能障害が遷延する場合には，ステロイ ド治療が考慮されるが, 現時点で大規模な二重 盲検の前向き研究等はなく, 今後の検討が必要 である。

\section{おわりに}

主に我が国における薬剤性腎障害の最近の動 向について概説した. 医学・薬学の進歩により, 多種多様な薬剤が病態に応じて複数用いられ, それに伴い，薬剤による有害事象も多くなるこ とが予想される。薬剤性腎障害は，AKIだけでな くCKDへと進展し, 最終的に末期腎不全へと移 行することが考えられ, 診断基準・治療法の確 立が重要である。診断の再現性・客観性を高め るために，スコアリングシステムの導入やバイ アスリスクの低い第三者による客観的な評価等 が考慮されるべきである。 また, 近年では, 遺 伝子解析により薬剤性腎障害発症と関連する因 子の探索も進んできている，有害事象に関与す る遺伝子変異を解析することは, リスクのある 患者集団を特定することにつながり，より安全 な薬刻を開発するうえで重要と考えられる，今 後は, データの集積, 得られたエビデンスの検 証, 国際比較等により, 診断基準, 予防及び治 療法の標準化が進むと考えられ，医療者はこれ 
らの情報のアップデート, 薬剤による有害事象 や薬剤間相互作用についての新しい知識の修得 が益々必要となる.
著者のCOI（conflicts of interest）開示：鶴岡秀一；講演 料（第一三共，大日本住友製薬，田辺三菱製薬，中外製 薬，日本ケミファ），研究費・助成金 (大塚製薬)，寄附 金 (アステラス製薬，協和発酵キリン，武田薬品工業， 田辺三菱製薬，中外製薬，鳥居薬品）

\section{文献}

1) Mehta RL, et al : Spectrum of acute renal failure in the intensive care unit : the PICARD experience. Kidney Int $66: 1613-1621,2004$.

2) Hoste EA, et al : Epidemiology of acute kidney injury in critically ill patients : the multinational AKI-EPI study. Intensive Care Med $41: 1411-1423,2015$.

3) Mehta RL, et al : Phenotype standardization for drug-induced kidney disease. Kidney Int 88 : 226-234, 2015.

4）薬剤性腎障害の診療ガイドライン作成委員会：薬剤性腎障害診療ガイドライン。日腎会誌 $58: 477-555,2016$.

5) Usui J, et al : Clinical practice guideline for drug-induced kidney injury in Japan 2016 : digest version. Clin Exp Nephrol $20: 827-831,2016$.

6）滝川 一: 薬物性肝障害の診断と治療. 日内会誌 $104: 991-997,2015$.

7) Bennett WM, et al : Drug-related syndromes in clinical nephrology. Ann Intern Med 87 : 582-590, 1977.

8) Loh AH, Cohen AH : Drug-induced kidney disease-pathology and current concepts. Ann Acad Med Singapore $38: 240-250,2009$.

9) Gurwitz JH, et al : Incidence and preventability of adverse drug events among older persons in the ambulatory setting. JAMA 289: 1107-1116, 2003.

10) Yokoyama H, et al : Drug-induced kidney disease : a study of the Japan Renal Biopsy Registry from 2007 to 2015. Clin Exp Nephrol 20 : 720-730, 2016. 